service to its members in Britain and abroad, conduct. ing research on problems presented by the companies. It also provides information on British and foreign legislation relating to food additives, cosmetics, packaging materials and pesticides, and it gives advice on the design, results and adequacy of toxicity tests carried out by the member companies. Because the Government insists on reviewing various groups of food additives every five years, an important part of the association's work each year involves carrying out additional tests on those groups coming up for review.

\section{Committee Power}

A REPORT of professional manpower published by five learned institutions in Britain last week is in the traditional mould. It sets out from the same premises, uses the same figures and predictably enough reaches much the same conclusions as the manpower reports already published. This is not surprising, as the authors of the previous reports, Dr F. S. Dainton, Mr G. S. Bosworth, Professor M. M. Swann and Lord Jackson, were all connected with the committce which has produced the latest report. The Council for Engineering Institutions set up the committee, whose aim it was to produce in abbreviated form the collective wisdom of the previous reports. The argument is that busy academics and businessmen have no time to consult the original sources, but would welcome being told the conclusions in an easily digested form.

As the report points out, the members of the committee served in their own capacities, not as representatives of the organizations which nominated them. The fact that members were nominated by the CEI, the Confederation of British Industry, the Royal Society, the Institute of Physics and the Physical Society (a single learned society, despite its name) and the Royal Institute of Chemistry is therefore not strictly relevant, though it is prominently displayed on the front of the broadsheet. After a few sentences from the Duke of Edinburgh, the report deals briskly with the problems, and goes on to suggest ways in which government departments, industry, professional institutions, universities and schools can help to solve them. The most sensible of the recommendations are those which lend support to the idea of much broader degrees at British universities, though the assumption that this would help to recruit more students to courses in science is not argued. The report accepts that there is "a serious shortage of highly qualified manpower", which is likely to get worse rather than better. To cure it, it suggests that the UGC should discriminate in favour of "disciplines that economic facts dictate are essential to community needs". 'This discrimination must start in the schools and continue in the universities, with grants (or loans, the report adds darkly) used as controls.

The report conveniently ignores reports published outside the British Isles, such as those recently produced by OECD on the technology gap. One of these contains some remarkable figures, which ought to have given the committee pause for thought. All those countries the economic performance of which is rated higher than that of Britain-the United States, France, Germany and Japan-produce fewer technologists as a proportion of the population at risk. The UK, according to OECD, is ahead of all other OECD countries in the production of technologists, and ahead of all but the United States in the production of scientists. One member of the committee had read the report, apparently, but no attempt was made to evaluate it. Perhaps the committee members simply refused to believe it, but if so they should have said so. In any case, there must be serious doubt whether industrialists and academics who have remained deaf to the pleas of the Jackson, Swann, Jones and Dainton reports will be moved by the obiter dicta of the CEI. The most amusing aspects of the report are those in which compromises have been necessary tiu secure the approval of the non-representatives of the CIBI. On the subject of the availability of risk-capital. for example, the committee could hardly give open support to the possibility that the Government might provide it through the Industrial Expansion Bill, because the CBI regards that as a mischievous measure. The report therefore calls on the Government to "foster a climate in which adequate provision can be made for risk finance for research and development projects of potential long-term benefit, and for their commercial exploitation". That could mean almost anything, or: nothing.

\section{More Nutrition Research}

A NEw extension to the Dunn Nutritional Laboratory, set amid the lush green background of Cambridge, was officially opened on June 17 by Sir Rudolph Peters and Dame Harriette Chick. Despite the garden party atmosphere, even a casual look around the superbly equipped new accommodation revealed that serious work is in progress and that every effort is being made to maintain the laboratory's excellent record under the directorship of Dr E. Kodicek.

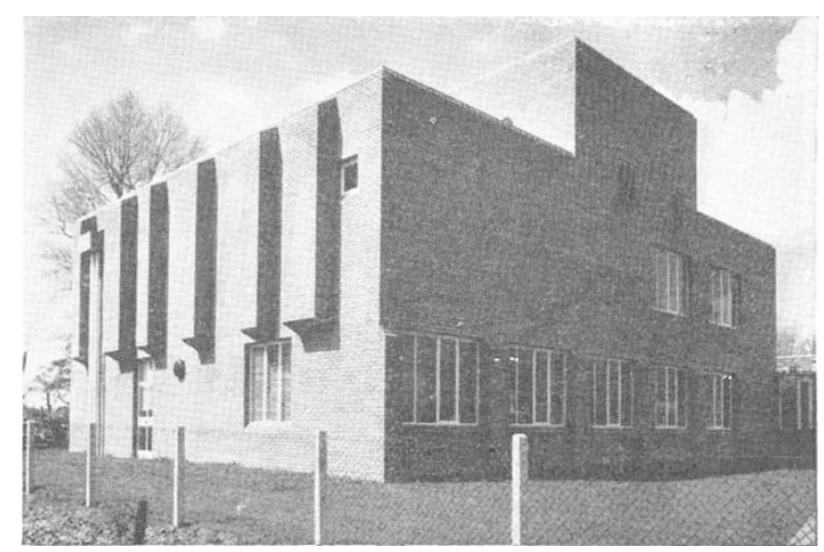

New extension to the Dunn Nutritional Laboratory.

The Dunn Nutritional Iaboratory was first established in Shaftesbury Road, Cambridge, in 1929 through the joint efforts of Sir Frederick Gowland Hopkins and Sir Walter Morley Fletcher-the then secretary of the Medical Research Council-to found a laboratory to be concerned with the physiology of human nutrition. The new extension, which was completed in February

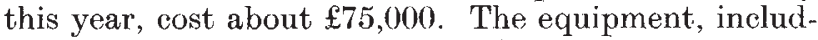
ing such items as an ultrasonic disintegrator, a Joyce Loebl Chromoscan densitometer, a spectrophotofluorometer and so on, is estimated to have cost another 